\title{
Modeling of Business Process Management of Academic Affair Information System
}

\author{
Wiranto Herry Utomo \\ Department of Information Systems \\ Satya Wacana Christian University \\ Diponegoro 52-60, Salatiga, Indonesia
}

\author{
Theophilus Wellem \\ Department of Information Systems \\ Satya Wacana Christian University \\ Diponegoro 52-60, Salatiga, Indonesia
}

\begin{abstract}
Misalignment between business process and information system is common in many organizations. Typically, the efforts to correct this misalignment do not bring results because of two factors: 1) the complexity of the information technology architecture derived from heterogeneous applications built on different architecture, programming languages, and platforms, and 2) the existing applications should be kept running when repaired. In order to align business process and information system, both should be integrated. The objectives of this research are: 1) to identify the business process of a university's Information System for Academic Affairs, 2) to analyze and design an automation of business process of a university's Information System for Academic Affairs, and 3) to identify the services needed for the automation and integration of business process and information system. The enterprise integration method used in this research is a combination of Service-oriented Architecture (SOA) and Model Driven Architecture (MDA). Using this combined method, the 13 academic affair business processes that currently implemented in Satya Wacana Christian University (SWCU) can be defined. Automating these 13 business processes can reduce the number of the business processes to only four processes. The services needed to be implemented as Web services to integrate all 35 unconnected information systems in SWCU were also successfully identified.
\end{abstract}

\section{General Terms}

Design, Theory, Experimentation

\section{Keywords}

Business Process Management, Service-oriented Architecture, Model-driven Architecture, Web services, Integration.

\section{INTRODUCTION}

Business process is a set of business activities that involve one or more inputs and create an output that has business value. Generally, business process develops at different speed compared to the information system. This problem will lead to the misalignment between business process and information system. Furthermore, it will also cause the information systems do not fully support business tasks. Sometimes there is a department in a company (organization) which is detached from the main business process and does not support business needs. As a result, the organization is becoming less flexible and difficult to adapt to the changes in the market. Only organizations whose applications can quickly and efficiently adapt to the business changes can remain competitive in the global marketplace.

\begin{abstract}
Misalignment between business process and information system is common in many organizations. Typically, the efforts to correct this misalignment do not bring results because of two factors: 1) the complexity of the information technology architecture derived from heterogeneous applications built on different architecture, programming languages, and platforms, and 2) the existing applications should be kept running when repaired.
\end{abstract}

In order to align business process and information system, both should be integrated. Several methods have been taken to manage and solve the misalignment of business process and information system. However, these methods are difficult to be achieved only by using traditional approaches. The approach that can be used to align business process and information system is Business Process Management. Business Process Management is a discipline to model, automate, manage, and optimize business process to improve profitability. By adopting Business Process Management, alignment of the various departments can be achieved. Therefore, it can increase the productivity of the company.

The objectives of this research are: 1) to identify the business process of a university's Information System for Academic Affairs, 2) to analyze and design an automation of business process of a university's Information System for Academic Affairs, and 3) to identify the services needed for the automation and integration of business process and information system.

\section{RESEARCH CONTRIBUTION}

As other universities in Indonesia, Satya Wacana Christian University (SWCU) has three main duties (known as University's Tri Dharma in Indonesian): 1) teaching, 2) research, and 3) community service. In order to fulfill these duties, SWCU is supported by several units such as library, finance and accounting, academic affairs, student organizations, and others. In this study, information system for academic affairs is all the information systems that related to business functions for student administration, from admission until graduation. The business functions include admission function, learning process, evaluation of learning outcomes, and graduation process.

Currently, information systems in SWCU only built to support specific business functions, whereas a university should have many business functions that require the support of information systems. Information systems in SWCU usually 


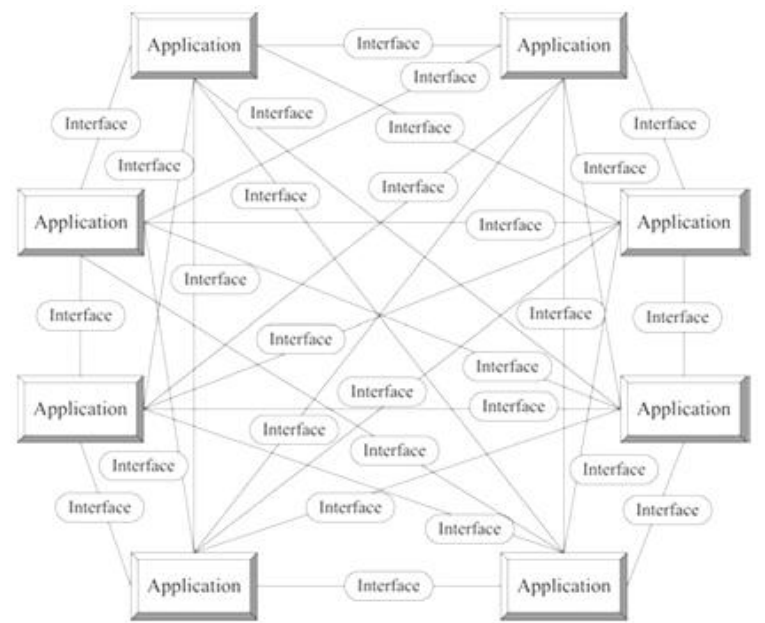

Fig 1: Point-to-point Integration Architecture [7]

were not aligned with the overall business objectives because the information systems were built only to meet short-term needs and do not consider business functions of other units.

In this case, there are 35 information systems in SWCU. Some of them are used to run some academic functions, such as SIASAT (Satya Wacana Academic Information System), SIKASA (Satya Wacana Financial and Accounting Information System) for payment of tuition fee, SIMARU (Satya Wacana Classroom Management Information System), and so on. The problem is that these 35 information systems are built separately, using the different platforms, different programming languages, and in different time period. The development of these information systems is only for certain business functions, which are managed by each unit separately, such that these information systems are not connected to each other. The existing information systems have not been able to support the automation of academic affair business processes that include student admission until student graduation. It also means there is no alignment between the existing information systems and the academic affair business processes. Therefore, information systems that can support the academic affair business processes, completely and thoroughly, which is not limited to a particular business function, but can be useful for all functional areas are needed. This requires the integration of a function-oriented system that can be aligned with the predefined academic affair business processes. However, the integration of existing information systems is not easy, because the existing information system is built using different platform, different programming language, in a different time, and for different purposes as well. Therefore, this integration can not be done with the existing traditional technologies. A new concept, known as enterprise integration, is needed as an effort to integrate the information systems in SWCU.

The enterprise integration method used in this research is a combination of SOA [1] and MDA [2, 3]. Using this combined method, the academic affair business process that will run its functions automatically can be defined. Based on the defined business process, the necessary services to automate the business processes can be identified. These services can be implemented as web services that will integrate these 35 information systems in SWCU. With this integration, the existing information systems do not need to be replaced and can still running as usual.

The advantages of the process-based software development are easier and faster to adapt to the change of business

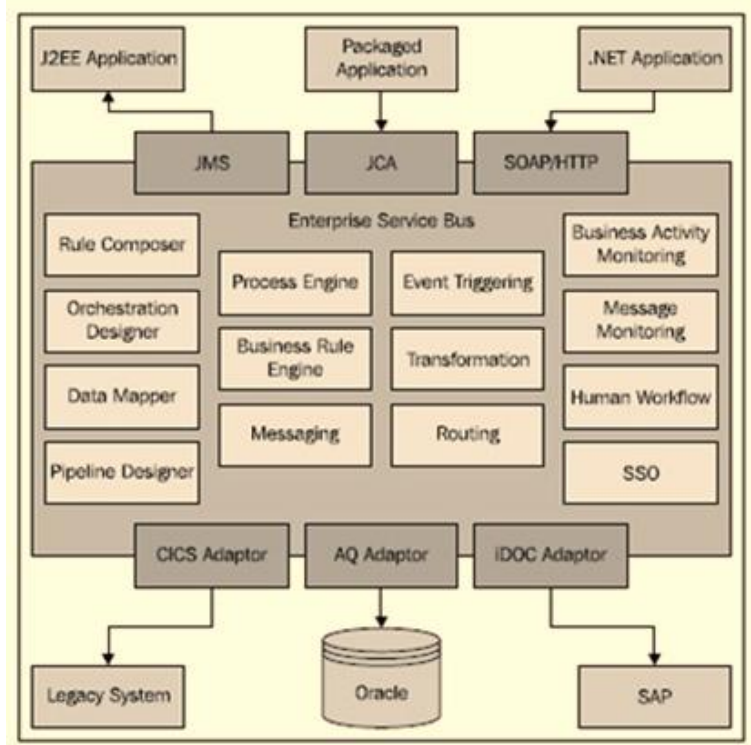

Fig 2: Architecture of Enterprise Service Bus [9]

systems. It also improves communication and collaboration among developers, because process-based software development is built on the collaboration among developers.

\section{SERVICE ORIENTED ARCHITECTURE}

According to Juric et al. [4], SOA is not a sudden, new architecture, but it is a result of the evolution of integration mode and distributed architecture. Before SOA, an interapplication integration method known as Enterprise Application Integration (EAI) has been developed. At first, EAI focused on the application integration in a company (intra-EAI), but in line with the development of the need of integration inter-companies (B2B, business-to-business), EAI focus is widened into inter-EAI. Intra-EAI integration means to integrate applications in the company by creating services as functionality of existing applications, while B2B integration or inter-EAI is related to message exchange outside company services.

SOA definition varies; there is no general definition for SOA. In this research, SOA concepts will be reviewed based on [5]. SOA, according to Erl [5], is software architecture developed using service oriented principles design. This service oriented design means that system functionalities are broken down into many smaller logical unit referred to as services.

Even though it gives obvious contribution, SOA has not been sufficient to carry out service based integration. There are some problems related to integration implementation in SOA: 1) no language support for modeling, 2) no guideline of the implementation of the services attained from services identification, and 3) services orchestration uses only Web service (WS). Therefore, SOA in itself has not been optimum to do the integration. This is the reason why other methods that can deal with SOA weaknesses are needed.

Based on the review and comparison of some integration methods, a method to help dealing with SOA weaknesses, MDA (proposed by OMG), is chosen. The decision to integrate MDA and SOA is based on: 1) MDA is a modeldriven method based on the use of free platform technology model, 2) MDA can be used to transform high level model business process to low level one (code), 3) the presence of standard modeling language, 4) MDA has used ESB as 


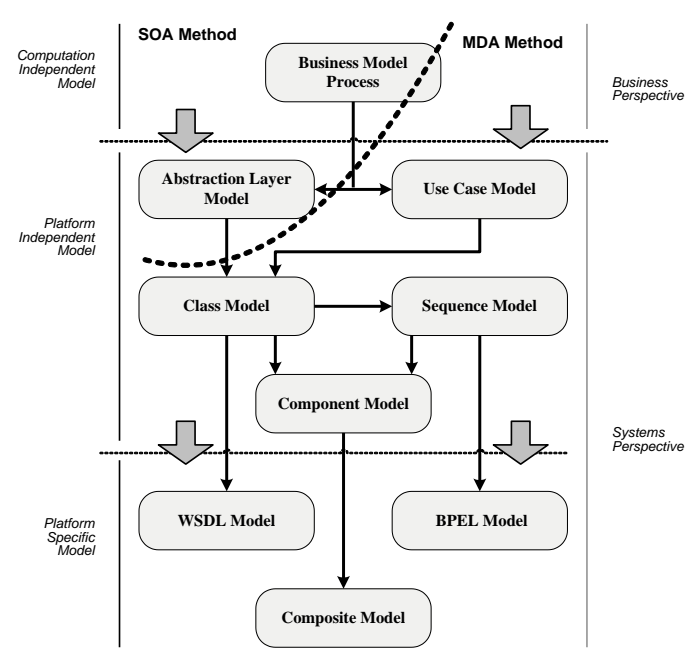

Fig 3: The SOA-MDA combination method [15]

middleware infrastructure, 5) the steps in MDA use life system development cycle.

The integration of MDA and SOA will give benefits that complement each other. SOA provides infrastructure that reduce complexity in reusing service and integrate all kinds of technology, protocol and application, whereas Business Process Definition Metamodel (BPDM) used in transforming high Business Process Model to low level model (programming code) that is platform-free.

According to Juric et al. [6], there are four integration architectures: 1) point-to-point, 2) hub-and-spoke, 3) enterprise message bus (JMS) and 4) SOA (Service-oriented Architecture).

Point-to-point integration architecture is a group of independent system connected through a network. The weakness of point-to-point integration architecture is that it cannot be widened and requires complicated application maintenance. This is related to the complexity in integrating applications using point-to-point architecture. In point-topoint integration architecture, the integration of $\mathrm{N}$ application to other $\mathrm{N}$ application needs $\mathrm{N}(\mathrm{N}-1) / 2$ interfaces. If there are six applications to be integrated, then 15 interfaces are needed, and for 150 applications, 11.175 interfaces are needed. Therefore, using point-to-point integration architecture, it will be more difficult for application maintenance and modification if the number of application is large [7].

Hub-and-spoke integration model is similar to point-to-point integration model. The difference is, there is one central hub that connects all applications. Message transformation and routing take place in the hub. This integration model is the improvement of the point-to-point integration model by reducing the number of connections (interfaces) needed for integration. Because the application is not directly connected to other applications, it can be eliminated from integration topology by removing it from the hub. This will reduce the chaos in integration management. However, hub-and-spoke integration model weakness lies on the centralized character of hub. If the hub experiences failure, the integration as a whole will experience the failure. Moreover, the problem of hub-and-spoke integration model is that its integration technology is locked by vendor.
While the hub-and-spoke integration model makes use of lightweight connectors to integrate applications through a

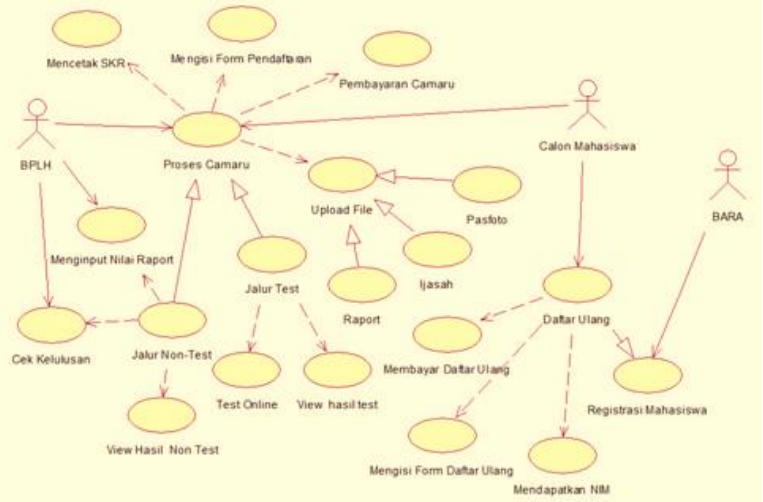

Fig 4: Use case diagram of New Student Registration

central hub, many times the integrated applications need to interact in a decoupled fashion, so that they can be easily added or removed without affecting the others. An enterprise message bus provides a common communication infrastructure, which acts as a platform-neutral and languageneutral adapter between applications. This communication infrastructure may include a message router and/or PublishSubscribe channels. Therefore, the applications interact with each other through the message bus, with the help of requestresponse queues [8].

SOA-ESB based integration uses services transferred through a middleware known as Enterprise Service Bus (ESB). SOA based integration concept is formerly present as a solution toward the problems of point-to-point integration complexity and hub-and-spoke integration. SOA is an architectural service based software application development. Therefore, there will be a light-binding in services integration. It allows the reuse of the existing services and production of easy and fast to build and change applications.

ESB is an infrastructure for SOA service connection and message exchange. The main functionality of ESB is to carry out route, protocol transformation, as well as message or data transformation. The presence of protocol transformation and message/data transformation functions in ESB can overcome protocol and data discrepancy. ESB also eases connection and mediation, simplifies integration, and eases the service components reuse, that results in high integration scalability [9].

\section{SOA-MDA METHOD}

SOA has gained a lot of attention for several research, whose contributions have been published in a significant number of new journals and conferences that have appeared within the scope of SOA systems. There is much previous research about the supporting or contradicting to this research. This previous research can be seen in Table 1 . 
Table 1. Comparison with previous studies

\begin{tabular}{|c|c|c|}
\hline References & Results & Weakness \\
\hline $\begin{array}{l}\text { Kumari et a1 } \\
(2008)[16]\end{array}$ & $\begin{array}{l}\text { Integrating new applications based on } \\
\text { J2EE, with legacy applications (Billing } \\
\text { System and Telecom Carier IBM } \\
\text { AS. } 400 \text { ) } \\
\text { Integration of intra-EAI using } \\
\text { Aqualogic Senvice Bus }\end{array}$ & $\begin{array}{l}\text { Not using standard } \\
\text { modeling }\end{array}$ \\
\hline $\begin{array}{l}\text { Hu et al }(2008) \\
\text { [17] }\end{array}$ & $\begin{array}{l}\text { Integration of different protocol using } \\
\text { ESB } \\
\text { Integration of intra-EAI using CORBA }\end{array}$ & $\begin{array}{l}\text { Not using standard } \\
\text { modeling }\end{array}$ \\
\hline $\begin{array}{l}\text { Gv-Zhang (2010) } \\
\text { [18] }\end{array}$ & $\begin{array}{l}\text { Integration of legacy application using } \\
\text { new business process and new business } \\
\text { services } \\
\text { Integration of intra-EAI using SCA }\end{array}$ & $\begin{array}{l}\text { Not using standard } \\
\text { modeling }\end{array}$ \\
\hline $\begin{array}{l}\text { He et al (2009) } \\
\text { [19] }\end{array}$ & $\begin{array}{l}\text { Integration of enterprise application } \\
\text { using Java } \mathrm{BE}, \mathrm{BAI} \text { and SOA } \\
\text { Integration of intra-EAI using Java } \mathrm{BE}\end{array}$ & $\begin{array}{l}\text { Stages of integration } \\
\text { is not clear }\end{array}$ \\
\hline $\begin{array}{l}\text { Yin et a1 }(2009) \\
{[20]}\end{array}$ & $\begin{array}{l}\text { Develop framework of JtangSynergy } \\
\text { using ESB for flexible distibuted } \\
\text { architecture } \\
\text { Integration of intr-EAI using } \\
\text { OpenESB }\end{array}$ & $\begin{array}{l}\text { Stages of integration } \\
\text { is not clear }\end{array}$ \\
\hline
\end{tabular}

This research uses the combination of SOA and MDA methods [15]. The combination of these methods is based on the thinking that each method in itself will not be optimum in integrating services. SOA itself can only provide services analysis and identification, but it does not provide guideline to implement services found. MDA method possess superiority in the transformation of high level Business Process Model to low level model (code) which is platform-free but without guideline in term of finding services. By combining MDA and SOA methods, two completing each other advantages will be gained. SOA provides an infrastructure that reduces complexity in the services reuse and integrates all kinds of technology, protocol, and application whereas MDA is used in High Level Business Process Model transformation to platform independent low level one (programming code). The combination of SOA and MDA methods will be a complete method for enterprise integration.

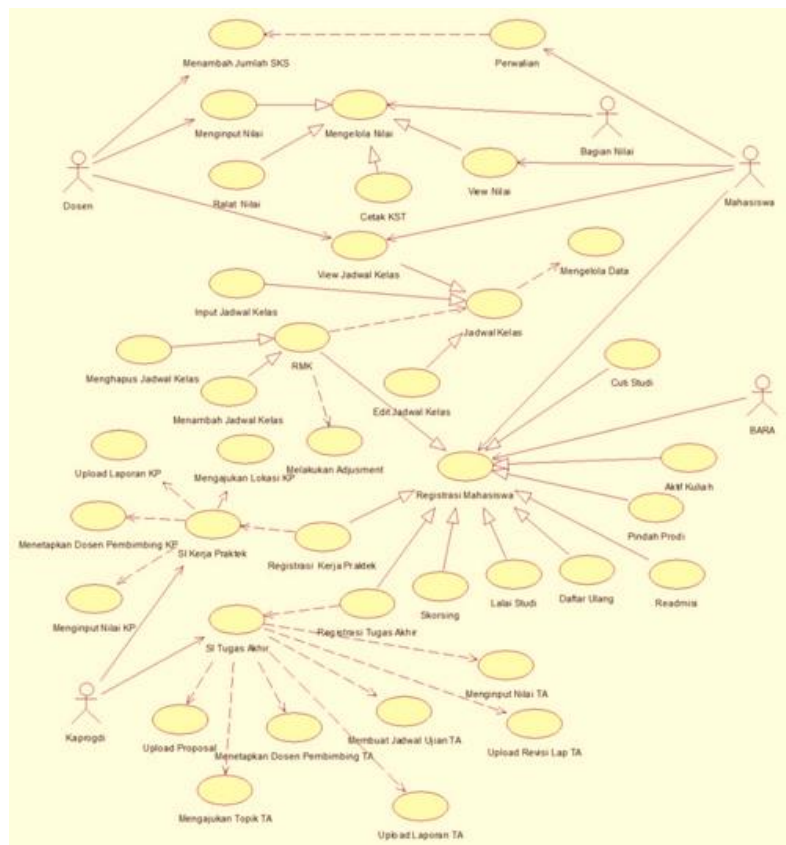

Fig 5: Use case diagram of Admission procedure

\section{RESULT AND DISCUSSION}

As described in Section 4, The SOA-MDA method consists of 9 stages (see Figure 3), namely Business Process Model, Use Case Model, Abstraction Layer Model, Class Model, Sequence Model, Component Model, WSDL Model, BPEL
Model and Composite Model. This research only covers three stages, Business Process Model, Use Case Model, and Abstraction Layer Model.

\subsection{Identification of current Business Process}

Currently, there are 13 business processes in SWCU's information system for academic affairs. The 13 business processes are: 1) New student Registration, 2) Reregistration, 3) Student Registration, 4) Courses Registration, 5) Academic Calendar Management, 6) Senior Project and Internship (KPTA) Management, 7) Academic Transcript Management, 8) Leave (Suspend) Study, 9) Active Study, 10) Re-admission, 11) Inter-Department Transfer, 12) Drop out, 13) Graduation.

\subsection{Business Process Automation for Academic Affairs}

Using SOA-MDA method, the 13 academic affair business processes that currently implemented in Satya Wacana Christian University (SWCU) can be defined and by automating these 13 business processes can reduce the number of the business processes to only four processes. The four business processes are: 1) New student Registration, 2) Admission Procedure, 3) Graduation, and 4) Data Management.

\subsubsection{New student Registration}

New student registration model is described in a use case diagram (see Figure 4). This modeling will result in the use case diagram and each use case will result in some scenarios according to the business processes that occur. The resulting use case diagram will describe the function of the overall system.

New students use case diagram consists of four actors: New Students, BPLH (New Student Selection Unit), BARA

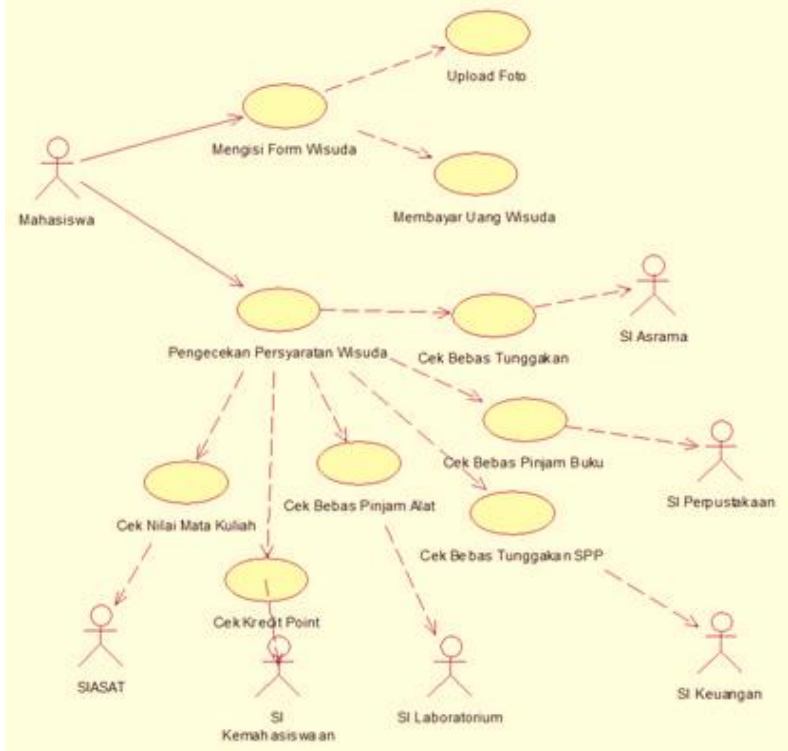

Fig 6: Use case diagram of Graduation

(Registration Unit) and the Bank and consists of 20 use cases or 20 functionalities. Some of the main functionality of the use case diagram is Mengisi form pendaftaran (fill registration form), Pembayaran camaru (new student candidate's registration payment), Upload file (file upload), Mencetak SKR (print SKR), Menginput nilai rapor (input student's grade), Cek kelulusan (graduation check), Mendaftar ulang 
(re-admission), Membayar daftar ulang (re-admission payment), Mengisi form daftar ulang (fill re-admission form), and Mendapatkan NIM (get new student ID/number).

\subsubsection{Admission procedure}

In this business process (see Figure 5) there were 5 actors: Dosen (lecturer), Mahasiswa (student), BARA (registration unit), Kaprogdi (department head), and Bagian Nilai (registrar office). Dosen can increase the number of credits, enter grade, and view the schedule of classes. Mahasiswa can look at the grade, view the class schedule and to student registration. Student registration consists of several activities that course registration, re-registration, re-admission, active study, interdepartment transfer, leave (suspend) study, drop out, and senior project and internship registration. Likewise BARA actor can also manage student registration. Actor Kaprogdi can manage senior project and internship management, while the actor Bagian Nilai can manage student's grade.

\subsubsection{Graduation}

In this business process (see Figure 6) there are 7 actors: Mahasiswa, SIASAT, SI Kemahasiswaan (student information system), SI Laboratorium (laboratorium information system), SI Keuangan/SIKASA,, SI Perpustakaan (library information system), and SI Asrama (student's dormitory information system). The main functionality of this business process is to fill out the graduation form, which includes uploading photos and graduation payment, as well as checking graduation requirements.

\subsubsection{Data Management}

In this business process (see Figure 7) there are 5 actors: Mahasiswa, Dosen, Kaprogdi, BARA, and Manajemen Ruang (room management). The main functionality of the business process is to manage student data, manage lecturer data, manage classroom data, and manage course data.

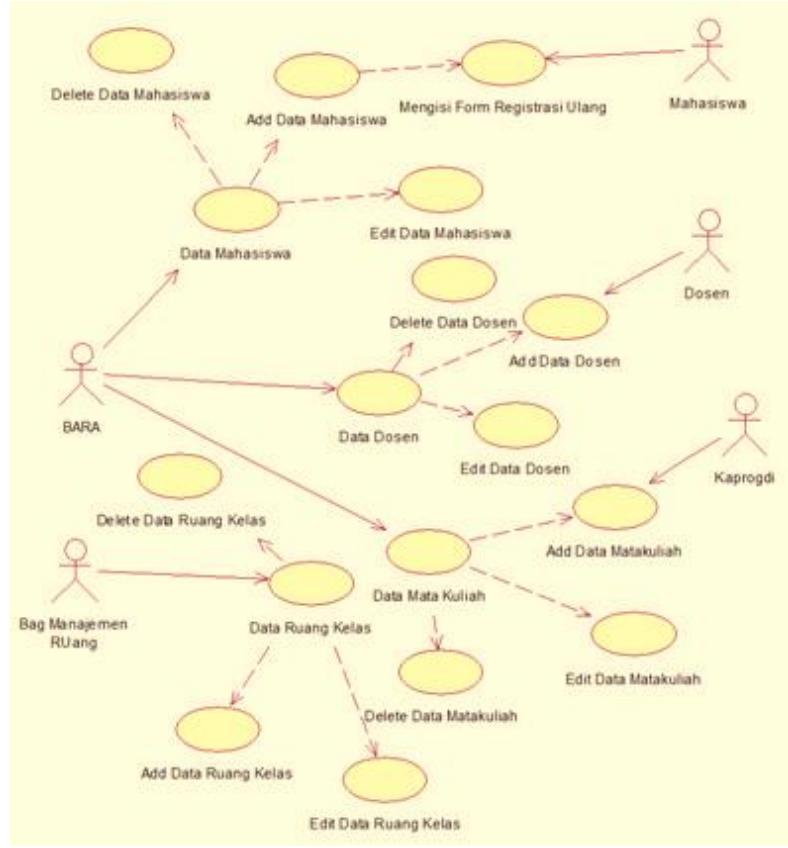

Fig 7: Use case diagram of Data Management

\subsection{Identification of Service candidate}

In this study, the identification of service candidates is done only at new student registration business process, as a proof for finding services. Identification of service candidates was performed in any existing layer on SOA (application service layer, business service layer, and orchestration service layer).
Identification of service candidates is based on the needs that have been obtained from the application model needs.

\subsubsection{Service candidate in Business Service Layer}

In the business service layer, the identification was done by looking at the existing business process that will be identified as a service candidate. Identification of service candidates in this layer can be done in two ways, namely entity-centric business service and task-centric business service. In identifying task-centric business service, besides using an existing business process, it is also identified from the usecase scenario in the use case model.

\subsubsection{Entity-Centric Business Service}

Entity-centric business service is done by identifying the entity that obtained from the new student registration business process. The result of this process led to the identification of three entities, is as follows: 1) New students, which is the entity that contains data about new students, such as new students ID/number, name, address, etc., 2) Pemamik (new student selection) Results, the entity that contains data about the Pemamik results such as camaru (new student candidate) code, information received, and 3) Test results, which is the entity that contains data about test results such as testimony received and new students ID/number. The three entities are going into services in the business service layer.

\subsubsection{Task-Centric Business Service}

Task-centric business service is obtained by mapping the steps in the new student registration business process to service candidates. Based on the steps of the new student registration business process, 15 service candidates are obtained. The result of this identification is shown in Table 1.

Table 1. Mapping of Business Process to Task-Centric Business Service Candidate

\begin{tabular}{|c|c|c|}
\hline No. & $\begin{array}{l}\text { Step of Business } \\
\text { Process }\end{array}$ & Service Candidate \\
\hline 1. & Mendaftar & $\begin{array}{l}\text { Service menginput data } \\
\text { camaru }\end{array}$ \\
\hline 2. & Pembayaran camaru & $\begin{array}{l}\text { Service memasukkan } \\
\text { data bukti }\end{array}$ \\
\hline 3. & Mengisi form camaru & $\begin{array}{l}\text { Service memasukkan } \\
\text { data camaru }\end{array}$ \\
\hline 4. & Memilih jalur tes & Service pilihan \\
\hline 5. & $\begin{array}{l}\text { Upload file ijasah dan } \\
\text { foto }\end{array}$ & Service upload file \\
\hline 6. & Mengikuti tes online & $\begin{array}{l}\text { Service koneksi ke web } \\
\text { tes online }\end{array}$ \\
\hline 7. & Menerima hasil tes & Service input hasil tes \\
\hline 8. & Memilih jalur non tes & Service pilihan \\
\hline 9. & $\begin{array}{l}\text { Upload file rapor dan } \\
\text { foto }\end{array}$ & Service upload file \\
\hline 10. & $\begin{array}{l}\text { BPLH menginput nilai } \\
\text { rapor }\end{array}$ & Service input rapor \\
\hline 11. & Menerima hasil non tes & $\begin{array}{l}\text { Service melihat dan } \\
\text { input hasil non tes }\end{array}$ \\
\hline 12. & Mendapatkan SKR & Service upload SKR \\
\hline 13. & $\begin{array}{l}\text { Mengisi form daftar } \\
\text { ulang }\end{array}$ & $\begin{array}{l}\text { Service input data } \\
\text { mahasiswa }\end{array}$ \\
\hline 14. & Membayar daftar ulang & $\begin{array}{l}\text { Service memasukkan } \\
\text { bukti pembayaran }\end{array}$ \\
\hline 15. & Mendapatkan NIM & Service mengirim NIM \\
\hline
\end{tabular}




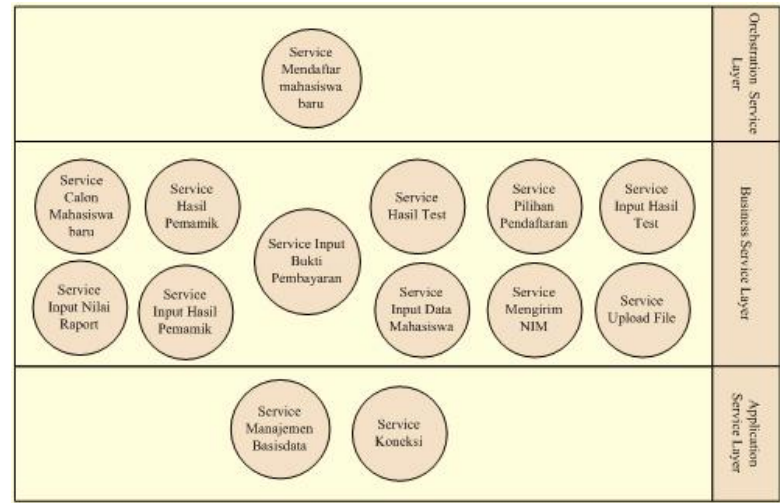

Fig 9: Final Service Candidate

\subsubsection{Service candidate in Application Service Layer}

Service candidate in the application service layer is the service needed by the application to execute the activities in the new student registration business process. In this study, it is known that it takes one service to organize new student data management in database. This service is not included in the business process as it is a technical function related to the database applications. This service must exist and can not be separated from the application. Services in the application service layer are the data management's services.

\subsubsection{Service candidate in Orchestration Service Layer} Service candidates of service orchestration layer are the services that performed the orchestration of services that exist at the lower layers (business service layer and application service layer). From the existing business process, it was found that the main business process is requested and updated the new students input data. Therefore, a service in the orchestration layer is needed to compose the services from business service layer and application service layer. This service is invoked by the application.

\subsubsection{Final Service candidate}

The service candidates are combined to produce 14 service candidates as shown in Figure 8. The 14 services that have been found will be implemented as web services. To implement these web services, it refers to Class Model, Sequence Model, Component Model, WSDL Model, BPEL Model and Composite Model of the SOA-MDA method.

\section{CONCLUSION}

Using SOA-MDA method, the 13 academic affair business processes that currently implemented in Satya Wacana Christian University (SWCU) can be defined. Automating these 13 business processes can reduce the number of the business processes to only four processes. The services needed to be implemented as Web services to integrate all 35 unconnected information systems in SWCU were also successfully identified.

\section{REFERENCES}

[1] Nikayin, F. A.: Adopting a Theoretical Method for the Development of a Service- Oriented Information System. Ph.D. Thesis, Faculty of Computer Science and Information Technology, University of Malaya, Kuala Lumpur, 2009.

[2] Pastor, O., Molina, J. C.: Model-Driven Architecture: in Practice a Software Production Environment based on Conceptual Modeling. Springer-Verlag, Berlin Heidelberg, 2007.
[3] Vos, W., Matthee, M. C.: Towards a Service-Oriented Architecture: A Framework for the Design of Financial Trading Applications in the South African Investment Banking Environment. South African Journal of Industrial Engineering, Vol. 22, May 2011, No. 1.

[4] Juric, M. B., Chandrasekaran, S., Frece, A., Hertis, M., Dan Srdic, G.: WS-BPEL 2.0 for SOA Composite Applications with IBM WebSphere 7. Packt Publishing, Birmingham, West Midlands, UK, 2010, pp. 644.

[5] Erl, T.: Service-Oriented Architecture: Concepts, Technology, and Design. Prentice Hall, Upper Saddle River, New Jersey, 2005.

[6] Juric, M. B., Loganathan, R., Sarang, P., Jennings, F.: SOA Approach to Integration. Packt Publishing, Birmingham, UK, 2007.

[7] Manouvrier, B., Menard, L.: Application Integration: EAI, B2B, BPM and SOA. John Wiley and Sons, Inc., Hoboken, New Jersey, USA, 2007.

[8] Binildas, C. A.: Service Oriented Java Business Integration. Packt Publishing, Birmingham-Mumbai, 2008.

[9] Schmutz, G., Liebhart, D., Welkenbach, P.: Serviceoriented Architecture: An Integration Blueprint. Packt Publishing, Birmingham, UK, 2010.

[10] Solamo, R., Antonio, J., Asrani, N., Chen, D., de Guzman, O., Feria, R., Petines, J. P., Shin, S., Srinivas, R., Thompson, M., Villafuerte, D.: Software Engineering, Java Education \& Development Initiative. Sun Microsystem, 2006.

[11] Almeida, J. P. A.: Model-Driven Design of Distributed Applications. Ph.D. Thesis, Centre for Telematics and Information Technology, University of Twente, Netherlands, 2006.

[12] Kim, H.: Modeling of Distributed Systems with SOA \& MDA. IAENG International Journal for Computer Science, Vol. 35, 20 November 2008, No. 4.

[13] Pokraev, S. V.: Model-Driven Semantic Integration of Service-Oriented Applications. Ph.D. Thesis, Centre for Telematics and Information Technology, University of Twente, Netherlands, 2009.

[14] Vidales, M. A. S., Garc'ia, A. M. F., Aguilar, L. J.: A New MDA Approach based on BPM and SOA to Improve Software Development Process. T'ekhne, Vol. VI, 2008, No. 9.

[15] Utomo, W.H., 2013. Integration of SME, Industry and Government through Public Infrastructure of SOA and Cloud Computing. Information Technology Journal, 12: 594-603. http://scialert.net/abstract/?doi=itj.2013.594.603

[16] Kumari,GP., Kandan,B., dan Mishra,AK., 2008, Experience sharing on SOA based Heterogeneous Systems Integration, IEEE Congress on Services 2008

[17] Hu, J., Luo, F., Li, J., Tong, X., dan Liao, G., 2008, SOA-based Enterprise Service Bus, International Symposium on Electronic Commerce and Security, Published by the IEEE Computer Society

[18] Gu, C. dan Zhang, X., 2010, An SOA Based Enterprise Application Integration Approach, Third International 
Symposium on Electronic Commerce and Security, Published by the IEEE Computer Society

[19] He, X., Li, H., Ding, Q., dan Wu, Z., 2009, The SOABased Solution for Distributed Enterprise Application Integration, International Forum on Computer ScienceTechnology and Applications, Published by the IEEE Computer Society
[20] Yin, J., Chen, H., Deng, S., Wu, Z., dan Pu, C., 2009, A Dependable ESB Framework for Service Integration, IEEE Internet Computing Journal, Published by the IEEE Computer Society 